\title{
Detoxification of Cyanide Wastewater by Cyanotrophic Organisms: the case of Phanerochaete chrysosporium*
}

\author{
${ }^{1}$ G. Ofori-Sarpong, ${ }^{2}$ A-S. Adam, ${ }^{1}$ R. K. Amankwah \\ ${ }^{1}$ University of Mines and Technology, Tarkwa, Ghana \\ ${ }^{2}$ Golden Star Prestea/Bogoso Resources, Bogoso, Ghana
}

Ofori-Sarpong, G., Adam, A-S. and Amankwah, R.K., (2020), "Detoxification of Cyanide Wastewater by Cyanotrophic Organisms: the case of Phanerochaete chrysosporium", Ghana Mining Journal, Vol. 20, No. 1, pp. 34 - 44.

\begin{abstract}
Cyanide, a carbon-nitrogen radical, is a major building block in many industries including pharmaceuticals, petrochemical and gold processing. In the gold extraction industry, cyanide has been the universal lixiviant for over a century due to better understood process chemistry, among others. Industries that discharge cyanide-laden effluents are mandated to keep concentrations below $0.2 \mathrm{mg} / \mathrm{L}$ to prevent death by cyanide-intoxification, which occurs when cyanide binds to key ironcontaining enzymes and prevent them from supplying oxygen-containing blood to the tissues. Techniques used to attenuate cyanide in wastewater can broadly be grouped into chemical, physical and biological methods. In recent times, attention has been placed on biotechnological methods, which make use of cyanotrophic microorganisms to clean up cyanidecontaminated environments. This paper reports on studies set out to assess the ability of Phanerochaete chrysosporium to degrade cyanide under different conditions including changes in cyanide concentration, culture mass, time, closed system and open system. At the end of 24-hour contact in an open agitated system with initial $\mathrm{pH}$ of 11.5, a control experiment using $100 \mathrm{mg} / \mathrm{L}$ cyanide revealed a natural attenuation of $15 \%$ with $\mathrm{pH}$ decreasing to 9.88 , while the best mycodetoxification of $85 \%$ was achieved by contacting $100 \mathrm{mg} / \mathrm{L}$ cyanide with $0.5 \mathrm{~g}$ culture mass, translating into degradation capacity of $17.2 \mathrm{mg} / \mathrm{g}$ (milligram of cyanide per gram of culture) with $\mathrm{pH}$ reducing to 8.4 in 24 hours. The degradation could be based on a number of mechanisms including hydrolysis to HCN, oxidation to cyanyl radical and cyanate due to natural attenuation through atmospheric contact, and secretion of organic acid, oxidative enzymes, and hydrogen peroxide by the fungus.
\end{abstract}

Keywords: Cyanotrophic Organism, Myco-Detoxification, Cyanide-Laden Effluents, pH

\section{Introduction}

\subsection{Cyanide and Its Usage in Gold Industry}

Cyanide contains the cyanogen $(\mathrm{CN})$ radical, formed from a triple-bond $(\mathrm{C} \equiv \mathrm{N})$ between unimolar amounts of carbon in the +2 oxidation state and nitrogen in the -3 oxidation state (Ahmad, 2004). The cyanide ion $\left(\mathrm{CN}^{-}\right)$is a ligand, with strong complexing ability that allows it to bond with almost all heavy metals in abiotic and biotic systems. Cyanide is found in a wide variety of life forms, and has applications in several industries including cassava starch making, electroplating, steel tempering, nuclear processing, photography, pharmaceuticals, pesticides, fumigants, petrochemicals, resins production, refining, coal and metal mining, processing and finishing industries (Akcil, 2003; Potivichayanon and Kitleartpornpairoat, 2010; Luque-Almagro et al., 2016; Kumar et al., 2017). Though cyanide plays a valuable role in several industries, mineral extraction industries account for the highest volume, as it makes use of cyanide in the extraction of gold and silver from large reserves of low-grade ores (Huiatt, 1984; Akcil, 2003; Kuyucak and Akcil, 2013).

Cyanide, chlorine, thiourea and thiosulphate are some of the lixiviants used in the mineral industry for the extraction of gold and silver from their ores/concentrates. However, cyanide has been the universal lixiviant among the lot for more than a century, due to factors such as low cost, well established process chemistry, high stability of the aurocyanide complex, and ease of recovery of gold from cyanidation with activated carbon (Marsden and House, 2006; Ofori-Sarpong and Osseo-Asare, 2013). Cyanidation is conducted normally at cyanide concentrations higher than the stoichiometric amount, and thus the effluent from cyanidation contains cyanide levels higher than those acceptable for safe discharge into the environment. It is estimated that more than three billion tonnes of gold and silver ores are treated via cyanidation annually, generating huge volumes of cyanide-laden effluents (Huiatt, 1984; Ebbs, 2004). Treatment of the waste to an environmentally- acceptable requirement is therefore very necessary to avoid surface and ground water contamination, pollution to the general environment and human beings. Mineral extraction companies that make use of cyanide are therefore regulated by the International Cyanide Management Code (Eisler and Wiemeyer, 2004; Donato and Overdevest, 2016) to keep the concentration of cyanide exiting their facility to below the maximum contaminant level of $0.2 \mathrm{mg} / \mathrm{L}$ (Kumar et al., 2017; Anon., 2018; 2019; 2020) prior to discharge into the environment. 


\subsection{Toxicity of Cyanide}

The cyanide can exist as a compound in organic and inorganic forms and as solid, aqueous and gaseous species. Cyanide can be classified broadly into three; Weak-Acid Dissociable (WAD), Strong-Acid Dissociable (SAD) and free cyanide (cyanide anion and hydrogen cyanide), which is the most toxic form of cyanide (Young and Jordan, 1995; Luque-Almagro et al., 2005; 2016; Kumar et al., 2017). WAD cyanide is cyanide complexed with such metals as nickel, copper, cadmium and zinc, whereas SAD cyanide is cyanide complexed with metals such as gold, silver, iron and cobalt. Thiocyanate $\left(\mathrm{SCN}^{-}\right)$is a $\mathrm{WAD}$, even though it is often considered in its own category. Cyanide is designated as P-listed hazardous waste, and thus, highly regulated in its disposal. Any form of cyanide is highly toxic and can be considered as a lethal suicide pill (L-pill) when it enters the human body (through inhalation, ingestion, and absorption) (Young and Jordan, 1995; Anon., 2019; 2020). Under moist environment, free or WAD cyanide dissociates to generate the most toxic form, hydrocyanic gas $[\mathrm{HCN}(\mathrm{g})]$ according to Fig. 1, with equilibrium of $\mathrm{CN}^{-}$and $\mathrm{HCN}$ occurring at $\mathrm{pH}$ of 9.3. Almost all the cyanide exists as the free cyanide ion present in solution at $\mathrm{pH}$ of 11.5 and as $\mathrm{HCN}$ at $\mathrm{pH} 7$ (Ozel et al., 2010; Cabello et al., 2018; Anon, 2019)

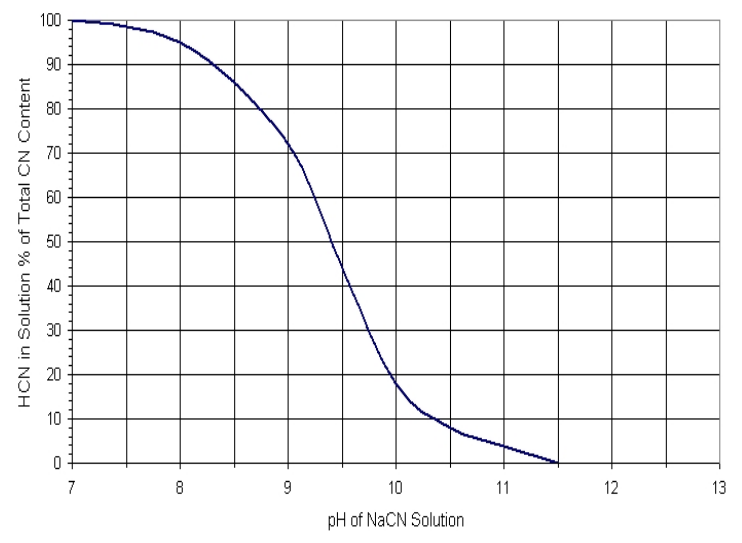

Fig. 1 Hydrolysis of Sodium Cyanide in Solution at $25^{\circ} \mathrm{C}$ (Ozel et al., 2010; Cabello et al., 2018)

Hydrocyanic gas has a vapour pressure of $100 \mathrm{kPa}$ relative to $34 \mathrm{kPa}$ for water at $26^{\circ} \mathrm{C}$, making the control of its movement difficult (Young and Jordan, 1995). The fatal doses of cyanide are 1-3 mg per $\mathrm{kg}$ body weight of human adults if ingested, $100 \mathrm{mg} / \mathrm{kg}$ body weight if adsorbed and 100-300 mg/L of HCN if inhaled (Huiatt, 1984). When exposed to a lethal dose without prompt first aid treatment, victims can suffer metabolic acidosis, coma, shock, seizures, bradycardia, and lack of response to oxygen treatment as cyanide ions bind to key iron-containing enzymes inactivating metalloproteins, such as cytochrome c oxidase. This blocks the mitochondrial electron transport chain preventing them from supplying oxygen from the blood to the tissues, thus inhibiting aerobic respiration which results in histotoxic hypoxia (Luque-Almagro et al., 2005; 2016; Anon., 2019; 2020).

\subsection{Biological Detoxification of Cyanide}

Conventional cyanide detoxification techniques predominantly involve separation or destruction, and may be grouped under physical, adsorption, complexation and/or oxidation methods, with the commonly used ones being the sulfur oxide/air, hydrogen peroxide and alkaline chlorination process (Akcil, 2003; Kitis et al., 2005; Kuyucak and Akcil, 2013). Degradation pathways are sensitive to the cyanide concentration and the physicochemical conditions such as oxygen concentration and $\mathrm{pH}$ of the media (Ebbs, 2004; Baxter and Cummings 2006; Kumar et al., 2017). Non-biological methods of $\mathrm{CN}^{-}$ detoxification results in long retention time, low selectivity, undestroyed thiocyanate, high reagent cost, cumbersome process and low effluent quality (Ebbs, 2004; Kumar et al., 2017; Cabello et al., 2018). Hence, there has been renewed interest in biological treatment technologies, which being a natural process, has positive public perception as an acceptable waste treatment process, especially with advances in biotechnology (Reybulck 1992; Dwivedi Naveen et al., 2011; Kumar et al., 2017).

Biodegradation of cyanide refers to the reactions by microoganisms from a diverse range of taxa that convert cyanide through a wide range of metabolic pathways into usable simple organic or inorganic molecules (Baxter and Cummings 2006). Despite its toxicity, some microorganisms, typically, bacteria and fungi are able to use their enzymatic system to convert cyanide into less toxic products like ammonia, formic acid and formamide which serve as sources of carbon and nitrogen for them (Shah et al., 1991;1993; Dubey and Holmes, 1995; Akcil, 2003; Hossain et al., 2005; Cabuk et al., 2006; Sethuramasamy et al., 2016; Cabello et al., 2018). Metabolic maps of cyanotrophic organisms are being developed with increased understanding of genomic, transcriptomic and proteomic techniques. Bacteria such as Pseudomonas sp. are known to degrade cyanide and thiocyanate under varying conditions of $\mathrm{pH}$, oxygen, temperature, nutrient levels and metal concentrations (Akcil et al., 2003; Luque-Almagro et al., 2005; Dwivedi Naveen et al., 2011; LuqueAlmagro et al., 2016; Kumar et al., 2017; Cabello et al., 2018). Fungal strains exploited for cyanide degradation include Trametes Versicolor, Rhizopus Oryzae, Pleurotus Sajor-caju, Trichloderma koningii, Gliocladium virens, and Fusarium spp. and $P$. chrysosporium (Cabuk et al., 2006). 


\subsection{Phanerochaete Chrysosporium and Cyanide Degradation}

Phanerochaete chrysosporium, a white rot basidiomycete, has been a model fungus in the investigation of lignin degradation which is centered on the creation of enzymatic system by extracellular glycosylated hemoperoxidases (Glenn et al., 1983; Tien and Kirk, 1984; Kirk et al., 1986; Dutton et al., 1993); typically, lignin peroxidase and manganese peroxidase, and hydrogen peroxide-generating enzyme, glyoxal oxidase. The lignin-degrading system of $P$. chrysosporium is extracellular and nonspecific, providing diversity in its application in degradation of a wide range of environmental pollutants (Bumpus et al., 1985; Cameron et al., 2000; Li et al., 2011; Xu et al., 2015) and transformation of recalcitrant components in gold ores (Ofori-Sarpong et al., 2010; 2011; 2013b; Liu et al., 2014; Konadu et al., 2017). A wide range of inexpensive media including millet, wheat bran, corn bran and corn cob within a temperature range of 20 $39{ }^{\circ} \mathrm{C}$ and $\mathrm{pH}, 2-11$ have been used in culturing the fungus, making it more cost-effective for environmental bioremediation (Shah and Aust, 1993; Ofori-Sarpong et al., 2010; 2017).

The conventional process used in extracting precious metals such as gold and silver for over a century has been cyanidation, which leads to the generation of cyanurated wastewaters that has the potential to harm the environment if not managed properly. These organizations that use cyanide are thus regulated by the International Cyanide Management Code (Eisler and Wiemeyer, 2004; Donato and Overdevest, 2016; Anon., 2019; 2020) to keep concentrations of cyanide at levels below $0.2 \mathrm{mg} / \mathrm{L}$ prior to discharge into the environment to avoid intoxification. Cyanide causes acute poisoning by binding to and incapacitating the key metalloenzymes, thus causing its victim to suffer unconsciousness. Researchers the world over have tried various methods in cyanide detoxification with some success stories (Akcil et al., 2003; LuqueAlmagro et al., 2005; Dwivedi Naveen et al., 2011; Kumar et al., 2017; Cabello et al., 2018). In recent years, advances in biotechnology have generated interest in the isolation, identification, and modification of cyanotrophic microorganisms, and in assessing their ability to detoxify cyanide under varying conditions (Cabello et al., 2018). With toxicity of cyanide being uncontrollable at neutral and acidic $\mathrm{pH}$, current research efforts are geared towards finding microbes that can degrade cyanide at alkaline $\mathrm{pH}$ to provide a more ecosociable biotechnological approach for removal of cyanide from industrial waste. Most of the work done on cyanide using Pharnerochaete chrysosporium have employed acidic and neutral $\mathrm{pH}$, and not much have been reported on success stories in alkaline media (Young et al., 1997; Ebbs, 2004; Hossain et al.,
2005; Luque-Almagro et al., 2016; Sethuramasamy et al., 2016; Cabello et al., 2018). This paper therefore sets out to investigate the ability of $P$. chrysosporium to attenuate cyanide in wastewater, at alkaline $\mathrm{pH}$ and under varying conditions, with the aim of contributing to the pull of knowledge in advancing cyanide metabolism by cyanotrophic organisms.

\section{Resources and Methods Used}

\subsection{Materials Used}

Analytical grade sodium cyanide, sodium hydroxide, and silver nitrate were obtained from Alfa Aeser. Fungal spores of Phanerochaete chrysosporium ME446, maintained on millet medium was obtained from Prof Ming Tien of Pennsylvania State University, USA. The growth media (millet) for the fungus was obtained from Nature's Pantry, State College, PA, USA, whereas corn cob was obtained from a waste disposal site in Tarkwa, Ghana. All other laboratory wares and chemicals were available in the Minerals laboratory of University of Mines and Technology, Ghana, where the experiments were conducted.

\subsection{Methods Employed}

The experimental work was carried out in the Minerals laboratory, University of Mines and Technology, Ghana. The work was categorized into various stages including medium preparation and culturing of fungus, preparation of cyanide solution and contacting with fungal culture, and determination of $\mathrm{pH}$ and cyanide strength. Parameters used in the detoxification process were $\mathrm{pH}$, residence time, cyanide concentration and fungal biomass dosage. The experiments were carried out in triplicate, and the data presented are average values.

\subsubsection{Medium Preparation and Culturing of Fungus}

The millet and corn cob (MCC) medium was prepared by mixing $5 \mathrm{~g}$ millet and $5 \mathrm{~g}$ corn cob crushed to all passing $3 \mathrm{~mm}$, in Erlenmeyer flasks with distilled water in the ratio of $1 \mathrm{~g} \mathrm{MCC:} 1 \mathrm{~mL}$ $\mathrm{H}_{2} \mathrm{O}$. The flasks were covered with aluminium foil and autoclaved at $121{ }^{\circ} \mathrm{C}$ for $30 \mathrm{~min}$. After cooling, the medium was inoculated with $1 \mathrm{~mL}$ of spore suspension of $P$. chrysosporium. The cultures were incubated in triplicates at $60 \%$ solids and $37{ }^{\circ} \mathrm{C}$ for 7 days (Ofori-Sarpong et al., 2010; 2017) in an MRC Orbital Incubator Shaker. Though the natural $\mathrm{pH}$ of the medium was between 6 and 7, the solution was conditioned to $\mathrm{pH} 11.5$ to assess survival of the fungus in the basic medium, and hence its ability to degrade cyanide at basic $\mathrm{pH}$. 


\subsubsection{Preparation of Cyanide Solution and Contacting with Fungal Culture}

Detoxification of cyanide was done in basic medium to prevent the volatilisation of hydrogen cyanide gas (Young et al., 1997; Ebbs, 2004; Luque-Almagro et al., 2005; Sethuramasamy et al., 2016; Cabello et al., 2018). Distilled water was conditioned to $\mathrm{pH} 11.5$ with sodium hydroxide, before contacting it with various amounts of solid sodium cyanide to reach solution concentrations of $10,20,50,100,200 \mathrm{mg} / \mathrm{L}$ of cyanide. A number of $250-\mathrm{mL}$ Erlenmeyer Flask holding $100 \mathrm{ml}$ of each concentration of cyanide solution was contacted with equivalent dry cultures of $0.25 \mathrm{~g}, 0.5 \mathrm{~g}, 1 \mathrm{~g}$ and $2 \mathrm{~g}$, for up to 24 hours. The flasks were covered with aluminium foil which was perforated with a hole of diameter about $0.3 \mathrm{~mm}$, and kept under slight agitation at $50 \mathrm{rev} / \mathrm{s}$ at a temperature of $37{ }^{\circ} \mathrm{C}$ in MRC Orbital Incubator Shaker. Control experiments were also set up under same conditions as described above, except that there was no addition of fungus. This was necessary to assess the exclusive ability of fungal biomass to effectively degrade cyanide. Two other controls were set up with no agitation; with one having the aluminium foil perforated (open system) and the other, not perforated (closed system).

\subsubsection{Determination of $\mathrm{pH}$ and Cyanide Strength}

At the end of the residence time, the $\mathrm{pH}$ of the residual solutions was measured using SPER Scientific Benchtop pH meter, and the drop, if any, was noted. The residual solution samples were also taken through silver nitrate-cyanide titration to determine the concentration of free cyanide. The silver nitrate solution was prepared by dissolving $1.733 \mathrm{~g}$ of silver nitrate in 1-L deionized water whereas rhodamine was prepared by dissolving $0.1 \mathrm{~g}$ of rhodamine in $20 \mathrm{ml}$ of ethanol, and topped-up to the 1-L mark. Two drops of rhodamine indicator were put into every cyanide sample and shaken well before titrating it with the silver-nitrate solution. Addition of rhodamine changed the color to yellow, and upon titration, a color change from yellow to brownish pink signified the end point.

\subsection{Analysis of Results}

The extent to which cyanide was degraded with and without myco-trophic activities was determined via titration with silver nitrate. The residual cyanide strength was determined using Equation 1, where $\left[\mathrm{CN}^{-}\right]$is the concentration of the residual cyanide solution after the degradation experiment and $\left[\mathrm{AgNO}_{3}\right]$ is the concentration of the silver nitrate solution used.

$$
\left[\mathrm{CN}^{-}\right]=\frac{\text { Volume of } \mathrm{AgNO}_{3}}{\text { Volume of } \mathrm{CN}^{-}} \times\left[\mathrm{AgNO}_{3}\right]
$$

The data obtained was analysed using basic statistics to determine the mean of the triplicate samples, and the means are represented in the figures. To determine the degradation capacity $(\mathrm{Q})$, which is the quantity of sodium cyanide biodegraded by a given fungal biomass, Equation 2 was employed, where $C_{i}$ and $\mathrm{C}_{\mathrm{f}}$ are the initial and final concentrations of cyanide solution in $\mathrm{mg} / \mathrm{L}, \mathrm{V}$ is the experimental volume of cyanide solution in $\mathrm{L}$, and $\mathrm{M}$ is the fungal biomass in grams (Patil and Paknikar, 1999; Sethuramasamy et al., 2016).

$$
Q=\frac{(\mathrm{Ci}-\mathrm{Cf}) \mathrm{V}}{\mathrm{M}}
$$

\section{Results and Discussion}

This paper assessed the ability of Phanerochaete chrysosporium to metabolise cyanide at basic $\mathrm{pH}$ in a bid to control the toxicity of cyanurated wastewater. Cyanide solution of various concentrations $(10,20$, 50,100 and $200 \mathrm{mg} / \mathrm{L}$ ) at $\mathrm{pH} 11.5$ were contacted with $0,0.25,0.5,1$, and $2 \mathrm{~g}$ of fungal biomass for up to 24 hours in open and closed containers under stationary and agitated conditions. The results and discussions are presented in four main sections; natural attenuation of cyanide, cyanotrophic ability of $P$. chrysosporium, effect of cyanide concentration and biomass on cyanide degradation, and correlation of cyanide degradation with solution $\mathrm{pH}$.

\subsection{Natural Attenuation of Cyanide}

Natural attenuation is used to describe all the processes that lead to a decrease in cyanide concentrations without human intervention. Cyanide solutions placed in shallow ponds undergo natural degradation. This is enhanced by greater contact with atmospheric carbon dioxide which lowers the $\mathrm{pH}$, increasing the rate of conversion to $\mathrm{HCN}$ and hence volatilisation (Patil and Paknikar 1999; Oudjehani et al., 2002). This attenuation is thus dominated by natural volatilization of hydrogen cyanide, but other reactions such as oxidation, hydrolysis, photolysis and precipitation also occur. Figure 2 depicts the results of the control experiment, where $100 \mathrm{~mL}$ of $100 \mathrm{mg} / \mathrm{L}$ cyanide solution at an initial $\mathrm{pH}$ of 11.5 was kept under various conditions for 24 hours without the addition of $P$. chrysosporium. 


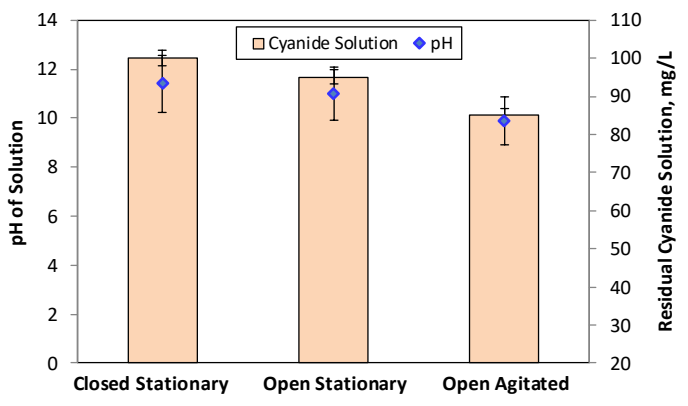

Fig. 2 Natural Degradation of Cyanide in the Absence of Fungal Biomass

The figure shows slow drops in $\mathrm{pH}$ and cyanide concentration of up to $15 \%$ depending on whether the solution was in closed or open containers, and whether they were subjected to agitation or not. From the figure, the $\mathrm{pH}$ and cyanide concentration remained constant throughout the 24 hours when the reaction vessel was covered with unperforated aluminium foil (closed system) and kept stationary, indicating there was no oxidation of cyanide or volatilization to hydrogen cyanide. In contrast, the containers covered with perforated aluminium foils (open system) showed up to 5\% and 15\% degradation respectively for the stationary and agitated systems at corresponding $\mathrm{pH}$ drops of 0.51 and 0.62 . The open system brings the free cyanide into contact with the moist environment, which can influence cyanide degradation through reduction in $\mathrm{pH}$, hydrolysis and oxidation (Patil and Paknikar 1999; Oudjehani et al., 2002).

\subsection{Cyanotrophic Ability of $P$. chrysosporium}

The ability of $P$. chrysosporium to degrade cyanide at $\mathrm{pH} 11.5$, which was assessed using $0.5 \mathrm{~g}$ of fungal biomass in an open agitated system, is compared with the trends obtained for natural attenuation as depicted in Fig. 3. In similitude to the control experiment, the initial cyanide concentration was $100 \mathrm{mg} / \mathrm{L}$, and the resident time was up to $24 \mathrm{hr}$. All the experiments with fungal biomass were conducted in open agitated systems to allow in oxygen as the rate of biodegradation is enhanced through the production of $\mathrm{H}_{2} \mathrm{O}_{2}$-an extra cellular oxidant secreted by $P$. chrysosporium (Kersten and Kirk, 1987; Hossain et al., 2005).

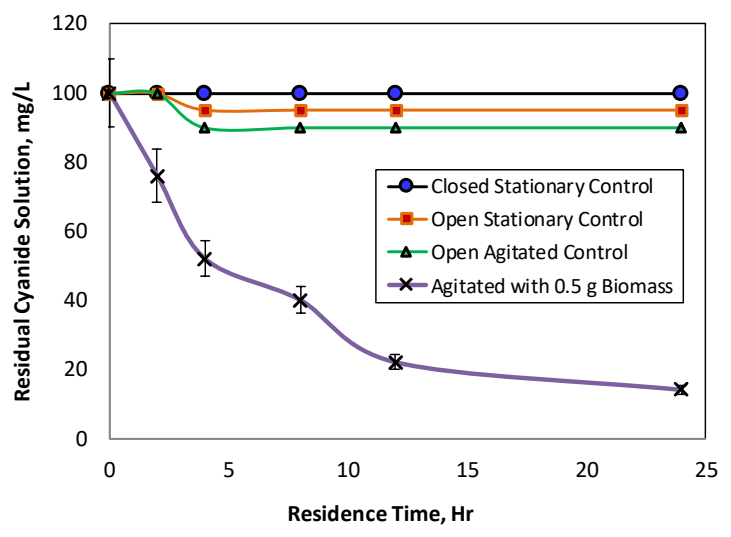

Fig. 3 Cyanotrophic Ability of $\boldsymbol{P}$. chrysosporium (Initial pH of 11.5, $100 \mathrm{~m} / \mathrm{L} \mathrm{CN}, 24 \mathrm{hr}$ )

Whereas the control experiments achieved a maximum of $10 \%$ cyanide degradation in 24 hours, the solution containing the $P$. chrysosporium realized about $85 \%$ cyanide degradation. The trends in Fig. 3 therefore affirm the capability of $P$. chrysosporium to act as a cyanotrophic organism as reported by other researchers (Shah and Aust 1993; Hossain et al., 2005; Cabuk et al., 2006). The ability of $P$. chrysosporium to degrade cyanide was studied by Shah and Aust (1993), who reported about $0.17 \pm$ $0.01 \mathrm{mmoles} /$ lit/day mineralization using $1.5 \mathrm{mM}$ $\mathrm{KCN}$ solution. Using crushed corn cobs as nutrient to cultivate $3000 \mathrm{ppm}$ CN-contaminated soil, the authors reported $10 \pm 0.75 \mathrm{ppm} /$ day mineralization of $\left[{ }^{14} \mathrm{C}\right]$-cyanide. Hossain et al. (2005) reported on about 93\% degradation of $100 \mathrm{ppm} \mathrm{AgCN}$ solution after inoculating it with $P$. chrysosporium for 96 hours within $\mathrm{pH}$ range of 3-7. The $\mathrm{pH}$ used by Hossain et al. (2005) can however cause cyanide to hydrolyze naturally, if not controlled well, thus masking the ability of the fungus.

\subsection{Effect of Cyanide Concentration and Fungal Biomass on Cyanide Degradation}

The ability of $P$. chrysosporium to degrade cyanide is influenced by the initial concentration of cyanide as presented in Fig. 4, and the biomass dose (Fig. 5). In all cases, the amount of cyanide degraded increased with contact time. Higher removal at the initial stage is due to high number of active sites for adsorption. These have been affirmed by other studies (Shah and Aust, 1993; Singh et al., 2017). 


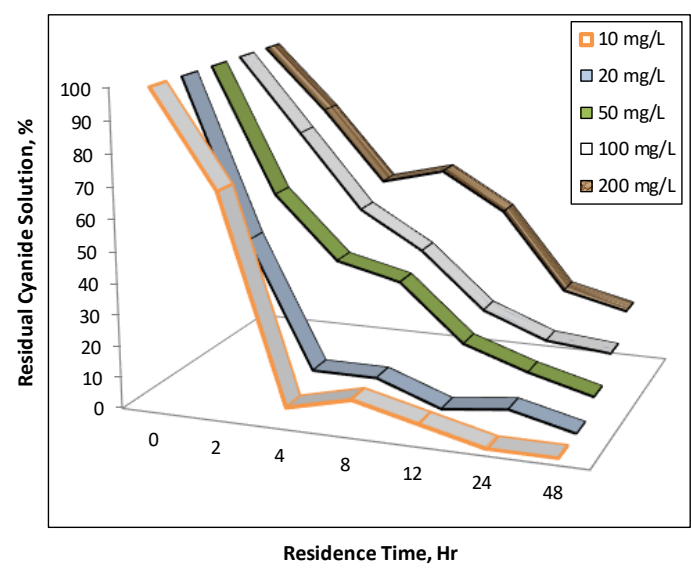

Fig. 4 Effect of Initial Cyanide Concentration on the Degradation of Cyanide as a Function of Contact Time. (Initial pH of 11.5, 10-200 $\mathrm{mg} / \mathrm{L} \mathrm{CN}, 0.5 \mathrm{~g}$ of Fungal Biomass, $48 \mathrm{hr}$ )

In Fig. 4, $100 \mathrm{~mL}$ of various cyanide concentrations $(10,20,50,100$ and $200 \mathrm{~m} / \mathrm{L})$ at an initial $\mathrm{pH}$ of 11.5 were contacted with $0.5 \mathrm{~g}$ of fungal biomass under open agitated condition for 48 hours. At the end of 24 hours, the corresponding residual cyanide solution as a percentage of the initial were $0,5,10,14$, and $25 \%$, decreasing further to $0,0,4.5,12$ and $20 \%$ respectively at the end of 48 hours. Several researchers have reported on biodegradation of sodium cyanide by bacteria and fungi. Notable among them is the use of the most studied Pseudomonas species, with the average being 9699\% degradation from $20-120 \mathrm{mg} / \mathrm{L}$ sodium cyanide solution at alkaline $\mathrm{pH}$ (Ackil et al., 2003; Huertus et al., 2010; Luque-Almagro et al., 2016). Cabuk et al. (2006), who used $0.2 \mathrm{~g}$ of biomass each of three fungi; Trametes versicolor, Phanerochaete chrysosporium and Pleurotus sajor-caju to assess the ability of white rot fungi to degrade $4000 \mathrm{mg} / \mathrm{L} \mathrm{KCN}$ at $\mathrm{pH} 10.5$ in 24 hours, recorded the highest degradation of about $15 \mathrm{mg} / \mathrm{L}$ for $P$. chrysosporium and about $30 \mathrm{mg} / \mathrm{L}$ for $T$. versicolor. In further studies where the authors used $0.75 \mathrm{~g}$ of $T$. versicolor in $150 \mathrm{mg} / \mathrm{L} \mathrm{KCN}$ at $30^{\circ} \mathrm{C}$ and $150 \mathrm{rpm}$, the authors reported about $90 \%$ cyanide degradation in 42 hours (Cabuk et al., 2006). The results in the present study suggests that in $24 \mathrm{hr}, 0.5 \mathrm{~g}$ of $P$. chrysosporium has the capacity to clean up cyanide wastewater removing about $90 \%$ from an initial concentration of $10-50 \mathrm{mg} / \mathrm{L}$, and $75-85 \%$ from an initial concentration of $100-200 \mathrm{mg} / \mathrm{L}$. With respect to WHO and EPA standard of $0.2 \mathrm{mg} / \mathrm{L} \mathrm{CN}$, the results here indicate that only the $10 \mathrm{mg} / \mathrm{L} \mathrm{CN}$ solution can be cleaned up effectively in 24 hours, whereas 10 $\mathrm{mg} / \mathrm{L}$ and $20 \mathrm{mg} / \mathrm{L} \mathrm{CN}$ solution can be cleaned up effectively in 48 hours using $0.5 \mathrm{~g}$ of the biomass. Nevertheless, the results obtained for the other concentrations also give a positive trajectory for further research.
Figure 5 demonstrates the effect of fungal biomass on the degradation of cyanide as a function of contact time. The experiment was conducted at an initial $\mathrm{pH}$ of 11.5 , and $100 \mathrm{~mL}$ of $100 \mathrm{mg} / \mathrm{L} \mathrm{CN}$ was contacted with varying fungal biomass $(0.25,0.5,1$ and $2 \mathrm{~g})$ for up to $24 \mathrm{hr}$. The figure shows an increasing capacity for cyanide degradation with increasing dose of fungal biomass and contact time. Within 12 hours of contact, $2 \mathrm{~g}$ of fungal biomass removed all the cyanide, while the $1 \mathrm{-g}$ biomass removed $91 \%$ and $95 \%$ respectively in 12 and 24 hours. The $0.5 \mathrm{~g}$ and $0.25 \mathrm{~g}$ biomass removed $85 \%$ and $40 \%$ cyanide respectively in 24 hours. The trend suggests that, under the conditions used in this work, an increased amount of culture mass will be required in degrading higher concentrations of solution. Notwithstanding the above, when the different weights of biomass were normalized using Equation 2 to determine their effective capacity in degrading $100 \mathrm{mg} / \mathrm{L}$ cyanide solution, the results showed higher capacities of 16 $\mathrm{mg}$ and $17 \mathrm{mg}$ for the smaller weights of biomass; $0.25 \mathrm{~g}$ and $0.5 \mathrm{~g}$. The higher quantities of biomass; 1 $\mathrm{g}$ and $2 \mathrm{~g}$ respectively, exhibited cyanide degradative capacity of $9.6 \mathrm{mg}$ and $5 \mathrm{mg}$ as demonstrated in Fig. 6. It could be summerised from Figs. 5 and 6 that the higher amounts of biomasses were not filled to capacity though the cyanide in the solution had been virtually depleted. With decrease in the amount of biomass, not all the cyanide could be removed but the slight agitation could expose a greater percentage of surface for interaction with cyanide. Effectively therefore, it is advisable and more efficient to treat the solution with batches of smaller amount of biomass. The two scenarios suggest that the removal efficiency may increase if smaller quantities of biomass are dosed intermittently into the cyanide solution rather than dosing higher amounts at once.

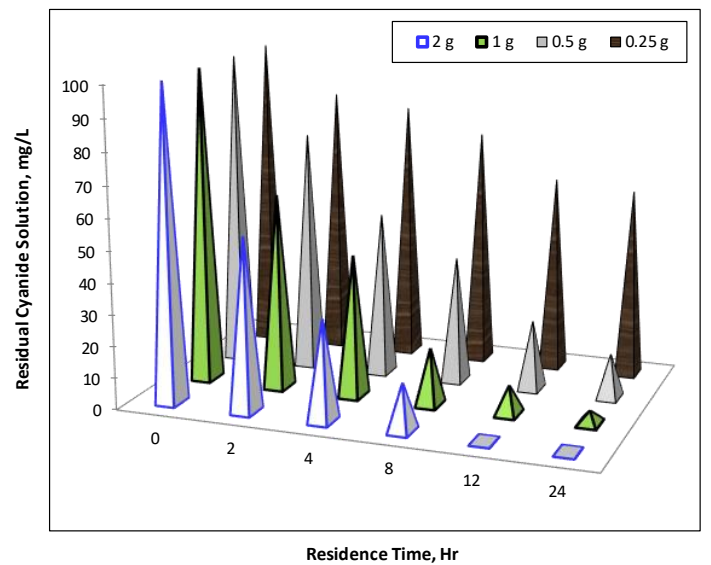

Fig. 5 Effect of Fungal Biomass on the Degradation of Cyanide as a Function of Contact Time. (Initial pH of 11.5, $100 \mathrm{mg} / \mathrm{L}$ CN, Varying Fungal Biomass, $24 \mathrm{Hr}$ ) 


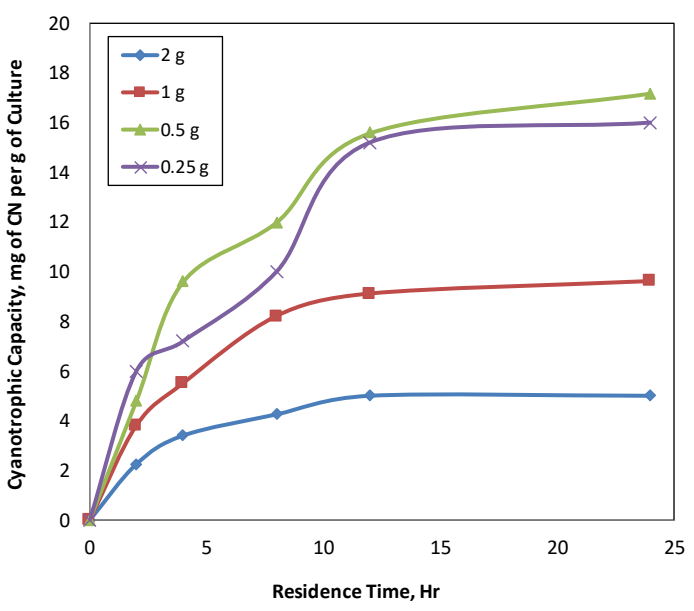

Fig. 6 Degradation Capacity, Mass of Cyanide Degraded per Unit Mass of Culture

\subsection{Correlation of Cyanide Degradation with Solution pH}

The reduction of $\mathrm{pH}$ over time during the metabolism of cyanide by $P$. chrysosporium is depicted in Fig. 7 . In 24 hours, there was a reduction of $\mathrm{pH}$ from 11.5 to 8.4 , with a reduction reaching $\mathrm{pH}$ of 9 within the initial 12 hours, and 7.5 at the end of 24 hours. Compared with the trends shown in Fig. 2, $15 \%$ natural degradation of cyanide was achieved at the end of 24 hours with $\mathrm{pH}$ dropping to 9.88 in the open agitated control system (without fungal biomass). This is indicative of a quicker reduction in $\mathrm{pH}$ resulting from the production of organic acids in the presence of the fungus (Dutton et al., 1993; Li et al., 2011; Zu et al., 2015). Acidification of the solution will thus remove cyanide from solution through the formation of hydrogen cyanide gas $[\mathrm{HCN}(\mathrm{g})]$ according to Equation 3 and Fig. 1, which indicates $\mathrm{pH}$ of 9.3 at equilibrium. Hydrocyanic gas has a vapor pressure of about $100 \mathrm{kPa}$ relative to $34 \mathrm{kPa}$ for water at $26^{\circ} \mathrm{C}$, and thus vaporizes easily (Young and Jordan, 1995; Anon., 2018).

$$
\mathrm{CN}^{-}+\mathrm{H}^{+} \rightarrow \mathrm{HCN}_{(\mathrm{g})}
$$

At $\mathrm{pH}$ of 9.5-9.1, which occurred at 8-12 hours, degradation of cyanide reached $61-67 \%$. The scatter plot in Fig. 8 also shows that an average of $65 \%$ cyanide degradation was realized at $\mathrm{pH}$ of 9.3 , and more than $90 \%$ degradation occurred at $\mathrm{pH} 7.5$ in the presence of the fungus. The above scenarios suggest that there are other degradation mechanisms aside hydrolysis as reported by other researchers (Ackil et al., 2003; Huertus et al., 2010).

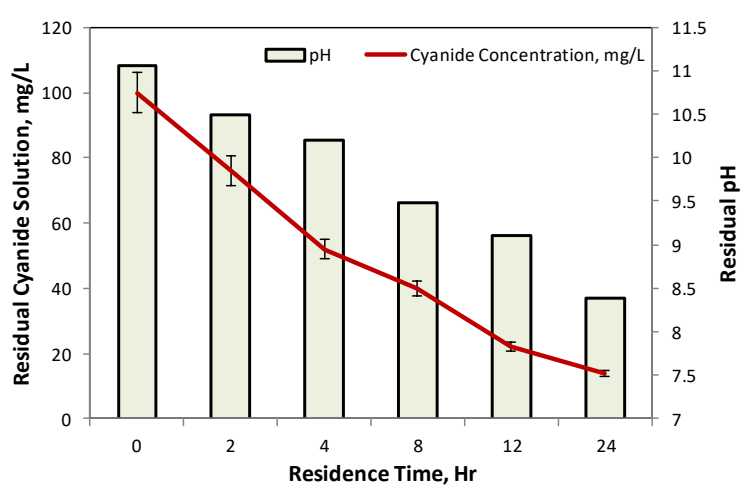

Fig. 7 Reduction in pH and Cyanide Concentration over Time (Initial pH of 11.5, $100 \mathrm{mg} / \mathrm{L} \mathrm{CN}, 0.5 \mathrm{~g}$ of Fungal Biomass, up to $24 \mathrm{Hr}$ )

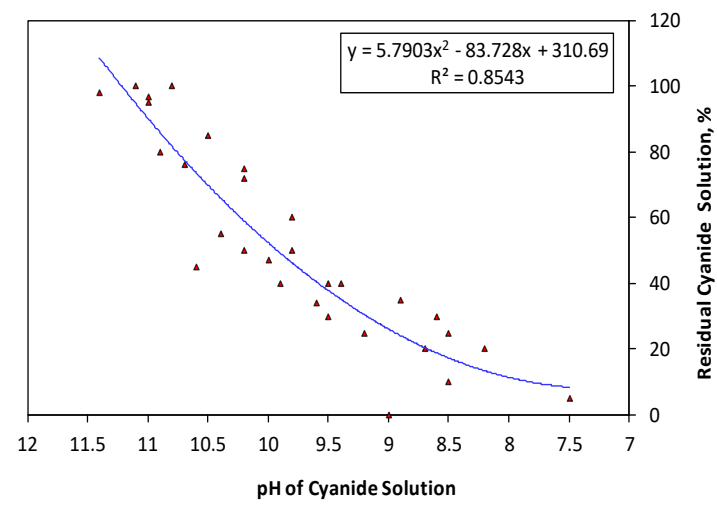

Fig. 8 Correlation of $\mathrm{pH}$ and Cyanide Degradation over Time (Initial pH of $11.5,100 \mathrm{mg} / \mathrm{L} \mathrm{CN}$, 0.5 g of Fungal Biomass, $24 \mathrm{Hr}$ )

\subsection{Proposed Mechanism of Cyanide Degradation by Phanerochaete Chrysosporium}

$P$. chrysosporium is well known to secret oxidative enzymes; lignin peroxidase, manganese peroxidase and glyoxal oxidase which create oxidizing environment for its degradative process (Tien and Kirk, 1983; Glenn et al., 1983; Kersten et al., 1987; Cameron et al., 2000). The oxidizing environment created by the fungus can oxidize cyanide to cyanyl radical according to Equations 4-6 modified after the mechanisms proposed for degradation of lignin and other carbonaceous materials by the fungus (Bumpus et al., 1985; Moreno et al., 1988; Stolze et al., 1989; Chen et al., 1999; Gold and Alic, 1993; OforiSarpong, 2013a). The enzyme, glyoxal oxidase generates hydrogen peroxide, which is used in activating the enzyme, lignin peroxidase, according to Equation 4, where lignin peroxidase, the native enzyme ( $\mathrm{P}[\mathrm{Fe}(\mathrm{III})])$ donates two electrons to form compound I $\left(P\left[O=\mathrm{Fe}(\mathrm{IV})^{\bullet+}\right]\right)$ and reduces hydrogen peroxide to water. Compound I then reacts 
with cyanide ion to generate a cyanyl or cyano radical $(\mathrm{CN} \cdot)$ and compound II, also react with another ion of cyanide, producing a cyano radical, while regenerating the native enzyme $\mathrm{P}[\mathrm{Fe}(\mathrm{III})]$ to go through the cycle again. The cyanyl radical, being unstable, may undergo a variety of non-enzymatic reactions and spontaneous rearrangements, leading to the formation of a wide range of other products (Bumpus et al., 1985; Gold and Alic, 1993; Shah and Aust 1993; Chen et al., 1999; Cabuk et al., 2006). Throughout the experiment, the $\mathrm{pH}$ of the cyanide solution decreased in the presence of the fungus, and this acidity generated can bring about hydrolysis of cyanide to hydrocyanic gas according to Equation 7. Hydrogen peroxide, such as generated by glyoxal oxidase, is a strong oxidant used in the oxidation of cyanide (Aronstein et al., 1994; Kitis et al., 1995; Young and Jordan, 1995; Kuyucak and Akcil, 2013) as shown in Equation 8.

$$
\begin{array}{r}
P[\mathrm{Fe}(\mathrm{III})]+\mathrm{H}_{2} \mathrm{O}_{2} \rightarrow \mathrm{P}\left[\mathrm{O}=\mathrm{Fe}(\mathrm{IV})^{\bullet+}\right]+\mathrm{H}_{2} \mathrm{O} \\
\mathrm{P}\left[\mathrm{O}=\mathrm{Fe}(\mathrm{IV})^{\bullet+}\right]+\mathrm{CN}^{-} \rightarrow P[\mathrm{O}=\mathrm{Fe}(\mathrm{IV})]+ \\
\mathrm{CN} \\
\mathrm{P}[\mathrm{O}=\mathrm{Fe}(\mathrm{IV})]+\mathrm{CN}^{-}+2 \mathrm{H}^{+} \rightarrow \mathrm{P}[\mathrm{Fe}(\mathrm{III})]+ \\
\mathrm{CN}^{\bullet}+\mathrm{H}_{2} \mathrm{O} \\
\mathrm{CN}^{-}+\mathrm{H}^{+} \rightarrow \mathrm{HCN}(\mathrm{g}) \\
\mathrm{CN}^{-}+\mathrm{H}_{2} \mathrm{O}_{2} \rightarrow \mathrm{CNO}^{-}+\mathrm{H}_{2} \mathrm{O}
\end{array}
$$

\section{Conclusions and Recommendations}

This paper assessed the ability of Phanerochaete chrysosporium to metabolise cyanide at basic $\mathrm{pH}$ in a bid to control the toxicity of cyanurated wastewater. A control experiment, where $100 \mathrm{~mL}$ of $100 \mathrm{mg} / \mathrm{L}$ cyanide solution at an initial $\mathrm{pH}$ of 11.5 was kept under a closed non-agitated condition for 24 hours without the addition of $P$. chrysosporium, no degradation occurred, and the cyanide concentration remained $100 \mathrm{mg} / \mathrm{L}$. The second control which was under open non-agitated condition realized $5 \%$ degradation with corresponding $\mathrm{pH}$ drops of 0.51 whereas the third under open and agitated condition revealed $15 \%$ cyanide degradation with $\mathrm{pH}$ drops of 0.62 . The results of the controls indicate the importance of air and light in natural attenuation of cyanide. When $0.5 \mathrm{~g}$ of $P$. chrysosporium was contacted with $100 \mathrm{~mL}$ of $100 \mathrm{mg} / \mathrm{L}$ cyanide solution at an initial $\mathrm{pH}$ of 11.5 for 24 hours, $85 \%$ degradation of cyanide was realized with $\mathrm{pH}$ dropping to 8.4. The rate of degradation generally reduced with increasing cyanide concentration, residence time and decreasing biomass. The effective capacity in degrading 100 $\mathrm{mg} / \mathrm{L}$ cyanide solution, however, showed higher capacities of $16 \mathrm{mg}$ and $17 \mathrm{mg}$ for the smaller weights of biomass; $0.25 \mathrm{~g}$ and $0.5 \mathrm{~g}$. In all cases, $\mathrm{pH}$ reduced in response to the production of acid by the fungus. The mechanisms proposed for the fungal degradation of cyanide include hydrolysis to hydrocyanic gas due to generation of acids, oxidation of cyanide to cyanyl by the action of the oxidative enzymes and oxidation to cyanate by hydrogen peroxide generated by the fungus. The present findings contribute to the pull of scientific knowledge, and will help in advancing the understanding of fungal cyanotrophy in alkaline media using white rot fungi.

\section{Acknowledgement}

This research did not receive any specific grant from funding agencies in the public, commercial, or notfor-profit sectors. The authors gladly acknowledge the assistance of Messrs Collins Donkor, Atta Adu Acheampong, Elvis Darko, and Keneth Konadu in gathering the laboratory data.

\section{References}

Ahmad, S. (2004), "The Chemistry of Cyano Complexes of Gold (I) With Emphasis on the Ligand Scrambling Reactions", Coord. Chem. Rev. Vol. 248, No.1-2, pp. 231-243.

Akcil, A. (2003), "Destruction of Cyanide in Gold Mill Effluents: Biological versus Chemical Treatments", Biotechnol Adv., Vol. 21, pp. 501511.

Akcil, A., Karahan A. G., Ciftci H. and Sagdic, O. (2003), "Biological Treatment of Cyanide by Natural Isolated Bacteria (Pseudomonas sp.)", Minerals Engineering. Vol. 16, pp. 643-649.

Anon. (2018), https://www.epa.gov/sites/production/files/2017-09/documents/cyanide technical_report (Accessed: December 20, 2018).

Anon. (2019), https://www.cyanidecode.org/ cyanidefacts/cyanide-chemistry (Accessed: May 25, 2019).

Anon. (2020), "Hazardous waste listings: A UserFriendly Reference Document" https://www.epa.gov/sites/production/files/2016-01/documents/hw_listref_sep2012.pdf (Accessed: January 20, 2020).

Aronstein, B. N., Maka, A., and Srivastava, V. J. (1994) "Chemical and Biological Removal of Cyanide from Aqueous and Soil-containing Systems," Appl. Microbiol Biotechnol., Vol. 41, pp. 700-707.

Baxter, J. and Cummings, S. P. (2006), "The Current and Future Applications of Microorganism in the Bioremediation of Cyanide Contamination," Atonie Van Leeuwenhoek., Vol. 90, pp. 1-17.

Bumpus, J. A., Tien, M., Wright, D. and Aust, S. D. (1985) "Oxidation of Persistent, Environmental Pollutants by a White rot Fungus", Science, Vol. 228, pp. 1434-1436.

Cabello, P., Luque-Almagro, V. M., Olaya-Abril, A., Sáez, L. P., Moreno-Vivián, C. and Roldán, M. D., (2018), "Assimilation of Cyanide and CyanoDerivatives by Pseudomonas pseudoalcaligenes CECT5344: from Omic Approaches to 
Biotechnological Applications", FEMS Microbiology Letters, Vol. 365, No. 6, doi: 10.1093/femsle/fny032.

Çabuk, A., Unal, A.T. and Kolankaya, N. (2006), "Biodegradation of Cyanide by a White Rot Fungus, Trametes versicolor", Biotechnology Letters. Vol. 28, No. 16, pp. 1313-1317.

Cameron, M., Timofeeski, S. and Aust, S. (2000), "Enzymology of Phanerochaete chrysosporium with respect to the Degradation of Recalcitrant Compounds and Xenobiotics", Appl. Microbial Biotechnol, Vol. 54, pp. 751-758.

Chen, Y-R., Sturgeon, B. E., Gunther, M. R. and Mason, R. P. (1999), "Electron Spin Resonance Investigation of the Cyanyl and Azidyl Radical Formation by Cytochrome c Oxidase", The Journal of Biological Chemistry, Vol. 274, No. 35, pp. 24611-24616.

Donato, D. Overdevest N. D. (2016), “Approaches to Cyanide Code Compliance for Tailings Storage Facilities", Gold Ore Processing, pp. 207-217.

Dubey S. K. and Holmes D. S. (1995), "Biological Cyanide Destruction Mediated by Microorganisms", World Journal of Microbiol Biotechnol, Vol. 11, pp. 257-265

Dutton, M. V., Evans, C. S., Atkey, P. T. and Wood, D. A. (1993), "Oxalate Production by Basidiomycetes, Including the White-Rot Species Coriolus versicolor and Phanerochaete chrysosporium. Appl Microbiol Biotechnol, Vol. 39, pp. 5-10.

Dwivedi, N., Majumber, C. B., Mondal, P. and Dwivedi, S. (2011). "Biological Treatment of Cyanide Containing Wastewater. Research Journal of Chemical Sciences. Vol. 1, No. 7, pp. 15-21.

Ebbs, S. (2004), "Biological Degradation of Cyanide Compounds", In: Current Opinion in Biotechnology, Environmental Biotechnology, Vol. 15, No. 3, pp 231-236.

Eisler, R. and Wiemeyer, S. N. (2004), "Cyanide Hazards to Plants and Animals from Gold Mining and Related Water Issues. In: Reviews of Environmental Contamination and Toxicology, Vol. 183, pp. 21-54.

Glenn, J. K., Morgan, M. A., Mayfield, M. B., Kuwahara, M., Gold, M. H. (1983), “An Extracellular $\mathrm{H}_{2} \mathrm{O}_{2}$-requiring Enzyme Preparation Involved in Lignin Biodegradation by the White Rot Basidiomycota Phanerochaete chrysosporium", Biochemical and Biophysical Research Communications, Vol. 114, pp. 1077-1083.

Gold, M. H. and Alic, M. 1993, "Molecular Biology of the Lignin-Degrading Basidiomycete Phanerochaete chrysosporium. Microbiology and Molecular Biology Reviews. Vol. 57, No. 3, pp. 605-622.

Hossain, S. M., Das, M., Begum, K. M. S. and Anantharaman, N. (2005), "Studies on Biodegradation of Cyanide using Phanerochaete chrysosporium", Journal of Institution of Engineers, Vol. 85, pp.45-49.

Huertas, M. J., Sáez, L. P., Roldán, M. D., LuqueAlmagro, V. M., Martínez-Luque, M., Blasco, R., Moreno-Vivián, C. and García-García, I. (2010), "Alkaline Cyanide Degradation by Pseudomonas pseudoalcaligenes CECT5344 in a Batch Reactor. Influence of pH", Journal of Hazard Mater, Vol. 179 , pp. $72-78$.

Huiatt, J. L. (1984) "Cyanide from Mineral Processing: Problems and Research needs," In: Proc. Conf. Cyanide and the Environment. Tucson, Arizona, pp. 65-81.

Kersten, P. J. and Kirk, T. K. (1987), "Involvement of a New Enzyme, Glyoxal Oxidase, In Extracellular $\mathrm{H}_{2} \mathrm{O}_{2}$ Production by Phanerochaete chrysosporium: Synthesized in the Absence of Lignin in Response to Nitrogen Starvation", Journal of Bacteriology, Vol. 135, pp. 790-797.

Kirk T. K., Croan, S., Tien, M., Murtagh, K. E. and Farrell, R. L. (1986), "Production of Multiple Ligninases by Phanerochaete chrysosporium: Effect of Selected Growth Conditions and Use of a Mutant Strain”, Enzyme Microb Technol Vol. 8, No. 1, pp. 27-32.

Kitis, M., Akcil, A., Karakaya, E. and Yigit, N. (2005), "Destruction of Cyanide by Hydrogen Peroxide in Tailings Slurries from Low-Bearing Sulphidic Gold Ores", Minerals Engineering, Vol. 18, pp. 353-362.

Konadu, K. T., Sasaki, K., Kaneta, T., Ofori-Sarpong, G. and Osseo-Asare, K. (2017), "BioModification of Carbonaceous Matters in Gold Ore: Model Experiments Using Powdered Activated Charcoal and Cell-Free Spent Medium of Phanerochaete chrysosporium", Hydrometallurgy, Vol. 168, pp. 76-83.

Kumar R., Saha S., Dhaka S., Kurade M. B., Kang C. U., Baek S. H. and Jeon B. (2017), "Remediation of Cyanide-Contaminated Environments through Microbes and Plants: A Review of Current Knowledge and Future Perspectives", Geosystem. Eng. Vol. 20, No. 1, pp. 28-40.

Kuyucak, N. and Akcil, A. (2013), "Cyanide and Removal Options from Effluents in Gold Mining and Metallurgical Processes", Minerals Engineering, Vol. 50-51, pp. 13-29. doi:10.1016/j.mineng.2013.05.027

Li, N. J., Zeng, G. M., Huang, D. L., Hu, S., Feng, C. L., Zhao, M. H., Lai, C., Huang, C., Wei. Z and Xie, G. X. (2011), "Oxalate Production at Different Initial $\mathrm{Pb}^{2+}$ Concentrations and the Influence of Oxalate during Solid-State Fermentation of Straw with Phanerochaete chrysosporium. Bioresoures Technology, Vol. 102, No. 17, pp. 8137-8142.

Liu, Q., Yang, H-Y. and Tong, L-1. (2014), "Influence of Phanerachaete chrysosporium Degradation and Preg-Robbing Capacity of Activated Carbon", 
Trans. Nonferrous Met. Soc. China, pp. 19051911.

Luque-Almagro, V. M., Huertas, M. J., MartínezLuque, M., Moreno-Vivián, C., Roldán, M. D., García-Gil, L. J., Castillo, F. and Blasco R. (2005), "Bacterial Degradation of Cyanide and its Metal Complexes under Alkaline Conditions", Appl Environ Microbiol, Vol. 71 pp. 940-947.

Luque-Almagro, V. M., Moreno-Vivian, C. and Roldan, M. D. (2016), "Biodegradation of Cyanide Wastes from Mining and Jewellery Industries", Current Opinion in Biotechnology, Vol. 38, pp. 9-13.

Marsden, J., House, I. (2006). The chemistry of gold extraction, $2^{\text {nd }} E d$., Society for Mining, Metallurgy and Exploration, Inc. Littleton, Colorado, pp 147-231.

Moreno, S. N., Stolze, K., Janzen, E. G. and Mason, R, P. (1988), "Oxidation of Cyanide to the Cyanyl Radical by Peroxidase/H2O2 Systems as Determined by Spin Trapping", Arch Biochem Biophys, Vol. 265, No. 2, pp. 267-71.

Ofori-Sarpong, G. and Osseo-Asare, K. (2013), "Preg-robbing of Gold from Cyanide and NonCyanide Complexes: Effect of Fungi Pretreatment of Carbonaceous Matter", International Journal of Mineral Processing, Vol. 119, pp. 27-33.

Ofori-Sarpong, G., Osseo-Asare K. and Tien, M., (2011), "Fungal Pretreatment of Sulfides in Refractory Gold Ores", Minerals Engineering, Vol. 24, pp. 499-504.

Ofori-Sarpong, G., Osseo-Asare, K., Osei, R. and Amankwah, R. K. (2017), "Assessing the Parameters for Optimum Biotransformation of Carbonaceous Matter by Phanerochaete chrysosporium" Advances in Bioscience and Bioengineering, Vol. 5, No. 6, pp. 107-114.

Ofori-Sarpong, G., Tien, M., and Osseo-Asare K. (2010), "Myco-hydrometallurgy: Coal Model for Potential Reduction of Preg-Robbing Capacity of Carbonaceous Gold Ores using the Fungus", Phanerochaete chrysosporium, Hydrometallurgy, Vol. 102, pp. 66-72.

Ofori-Sarpong, G.,Amankwah, R. K. and OsseoAsare, K. (2013a), "Reduction of Preg-robbing by Biomodified Carbonaceous Matter - A Proposed Mechanism", Minerals Engineering, Vol. 42, pp. 29-35.

Ofori-Sarpong, G.,Osseo-Asare, K. and Tien, M. (2013b), "Mycohydrometallurgy: Biotransformation of Double Refractory Gold Ores by the Fungus, Phanerochaete chrysosporium", Hydrometallurgy, Vol. 137, pp. 38-44.

Oudjehani, K., Zagury, G. J. and Deschênes L. (2002), "Natural Attenuation Potential Of Cyanide Via Microbial Activity In Mine Tailings", Appl Microbiol Biotechnol, Vol. 58, pp. 409-415.

Ozel, Y. K. 1., Gedikli, S., Aytar, P., Unal, A., Yamaç, M., Cabuk, A. and Kolankaya, N. (2010), "New Fungal Biomasses for Cyanide Biodegradation”.
Journal of Bioscience and Bioeng., Vol. 110, No. 4, pp. 431-435.

Patil, Y. B. and Paknikar, K. M. (1999), "Removal and Recovery of Metal Cyanides using a Combination of Biosorption and Biodegradation Processes", Biotechnology Letters, Vol. 21, pp. 913-919.

Potivichayanon, S. and Kitleartpornpairoat, R. (2010), "Biodegradation of Cyanide by a Novel Cyanide-degrading Bacterium", World Academy of Science Engineering and Technology, Thailand, pp. 42.

Raybuck, S. A. (1992), "Microbes and Microbial Enzymes for Cyanide Degradation", Biodegradation, Vol. 3, pp. 3-18.

Sethuramasamy, P. K., Asha, D. N. and Bhuvaneshwari, D. S. (2016), "Biosorption of Cyanide using Bacillus cereus from Salt Pan, Tuticorin, Tamilnadu - Isotherm and Kinetic Studies", Journal of Indian Chemical Society. Vol. 93, pp. 211-222.

Shah, M. M. and Aust, S. D. (1993), "Degradation of Cyanides by the White Rot Fungus Phanerochaete chrysosporium, Emerging Technologies in Hazardous Waste Management III Chapter 10, ACS Symposium Series, Vol. 518, pp 191-202.

Shah, M. M., Grover, T. A. and Aust, S. D. (1991) "Metabolism of Cyanide by Phanerochaete chrysosporium”, Arch. Biochem. Biophys. Vol. 290, pp.173-178.

Singh, N., Agarwal, B., \& Balomajumder, C. (2016), "Simultaneous Treatment of Phenol and Cyanide Containing Aqueous Solution by Adsorption, Biotreatment and Simultaneous Adsorption and Biotreatment (SAB) Process. Journal of Environmental Chemical Engineering, Vol. 4, No. 1, pp. 564-575.

Stolze, K., Moreno, S. N. and Mason, R. P. (1989), "Free Radical Intermediates formed during the Oxidation of Cyanide by Horseradish Peroxidase $/ \mathrm{H}_{2} \mathrm{O}_{2}$ as Detected with Nitroso Spin Traps", Journal of Inorganic Biochemistry, Vol. 37, No. 1, pp. 45-53.

Tien, M. and Kirk, T. K. (1983), "Lignin-degrading Enzyme from the Basidiomycete Phanerochaete chrysosporium" Burds, Science, Vol. 221: pp. 661-663.

Xu, P., Leng, Y., Zeng, G., Huang, D., Lai, C., Zhao, M., Wei, Z., Li, N., Huang, C., Zhang, C., Li, F. and Cheng, M. (2015), "Cadmium Induced Oxalic Acid Secretion and its Role in Metal Uptake and Detoxification Mechanisms in Phanerochaete chrysosporium", Appl Microbiol Biotechnol, Vol. 99, No. 1, pp 435-43, doi: 10.1007/s00253-0145986-y.

Young, C. A. and Jordan, T. S. (1995), "Cyanide Remediation: Current and Past Technologies" Proceedings of the 10th Annual Conference on Hazardous Waste Research, Kansas State 


\section{Authors}

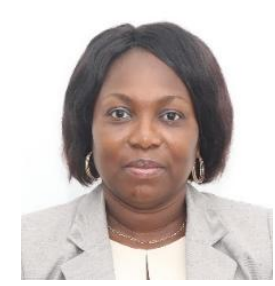

G. Ofori-Sarpong is an Associate Professor of Minerals Engineering at the University of Mines and Technology, Tarkwa. She holds $\mathrm{PhD}$ in Energy and Mineral Engineering from Pennsylvania State University, MSc in Environmental Resources Management and BSc in Metallurgical Engineering, both from the Kwame Nkrumah University of Science and Technology, KNUST, Kumasi, Ghana. She is a Fellow of Ghana Academy of Arts and Sciences and West African Institute of Mining, Metallurgy and Petroleum (WAIMM). She is also a member of the Society for Mining, Metallurgy and Exploration Engineers (SME), Society of Petroleum Engineers (SPE) and the Founder and President of Ladies in Mining and Allied Professions in Ghana. Her areas of research interest include microbial-mineral interaction, environmental biohydrometallurgy, acid mine drainage issues and precious minerals beneficiation.

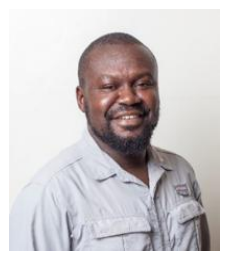

A-S Adam is the General Manager and Director for Golden Star's Bogoso/Prestea Mine. He holds BSc (Hons) and MPhil Degrees in Minerals Engineering from the Western University College of KNUST and University of Mines and Technology, Tarkwa (UMaT), respectively. He is a $\mathrm{PhD}$ candidate in UMaT. He has Process/Metallurgical Manager certificates of competency from the Inspectorate Division of the Minerals Commission of Ghana and is a Professional member of the Society for Mining, Metallurgy and Exploration Engineers (SME) and Australasian Institute of Mining and Metallurgy (AusIMM). His areas of research interest include microbially enhanced recovery of minerals, precious metal beneficiation, biotechnology of industrial wastewater.

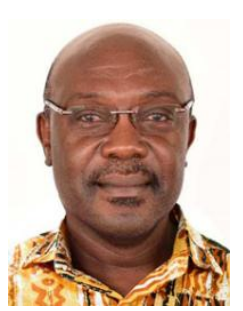

R. K Amankwah is a Professor of Minerals Engineering at the University of Mines and Technology (UMaT), Tarkwa, Ghana. He holds a PhD degree in Mining Engineering from Queen's University, Canada, and MPhil and BSc in Metallurgical Engineering from the Kwame Nkrumah University of Science and Technology, KNUST, Kumasi, Ghana He is a Fellow of the West African Institute of Mining, Metallurgy and Petroleum (WAIMM), a member of the Ghana Institution of Engineers and the Society for Mining, Metallurgy and Exploration Engineers (SME). His research interests include gold beneficiation, water quality management, microwave processing of minerals, small-scale mining, medical geology, microbial mineral recovery and environmental biotechnology. 